\title{
Impact of Board Characteristics on Bank Risk: The Case of Vietnam
}

\author{
Tu T. T. TRAN ${ }^{1}$, Nhung H. DO², Yen T. NGUYEN ${ }^{3}$
}

Received: June 14, 2020 Revised: July 05, 2020 Accepted: August 10, 2020

\begin{abstract}
The research identifies hypotheses evaluating the impact of board characteristics on the risk of the commercial bank as well as examining the determinants of bank risk in Vietnam over a 10-year period, starting from 2008. Also, in this research, the differences between the roles of women and men in decision-making are tested. Based on this decision, risks of the banks may arise. Ordinary least squares (OLS) regression, Random effect method, and Fixed effect method are used to estimate the factors that have an impact on bank risk for dataset of all commercial banks in Vietnam. The results found that equity-to-asset ratio, bank performance and the economic growth have an inverse relationship with bank risk, while the size of bank has a positive relationship with the bank risk. One of the highlights of this paper is a demonstration of the relationship between CEO's gender and bank risk. The test result shows that the bank led by a female faces a higher overall risk level and credit risk than a bank led by a male. Based on this result, the paper also makes recommendations to Government, the State Bank of Vietnam and the commercial banks for effective risk management.
\end{abstract}

Keywords: Commercial Bank, Risk Management, Bank Risk, Board Characteristics

JEL Classification Code: G20, G21, G41

\section{Introduction}

The financial crisis 2008 is considered a turning point that has changed the attitude of businesses, especially the financial institutions. Instead of only concentrating on addressing the previous weakness and inefficiency, the financial intermediation also focuses on the change to reduce the likelihood and severity of future crises. To design a strategy, instead of just focusing on business performance, financial institutions also use risk management reports to support decision-making. Therefore, studying and examining objectively determinants of bank risk plays a meaningful

${ }^{1}$ First Author, Associate Professor, Finance and Banking Faculty, University of Economics and Business, Vietnam National University, Vietnam. Email: tuttt@vnu.edu.vn

${ }^{2}$ Corresponding Author, Lecturer, School of Banking and Finance, National Economics University, Vietnam [Postal Address: 207 Giai Phong Road, Hai Ba Trung District, Hanoi, 100000, Vietnam] Email: nhungdh@gmail.com

${ }^{3}$ Lecturer, Economics Faculty, University of Vinh, Vietnam. Email: yennguyen1507@gmail.com

(C) Copyright: The Author(s)

This is an Open Access article distributed under the terms of the Creative Commons Attribution Non-Commercial License (https://creativecommons.org/licenses/by-nc/4.0/) which permits unrestricted non-commercial use, distribution, and reproduction in any medium, provided the original work is properly cited. role in the bank's risk management and strategic decisionmaking.

With an increasingly developed society, women have made an ever more important contribution to the economy. The female workers have participated in many fields and increasingly asserted their positions. The General Statistics Office in Vietnam shows that women make up $48 \%$ of the country's labor force and hold $36 \%$ of the senior leadership positions, which is ranked the second highest among Asian countries in 2019 according to the latest Women in Business research from Grant Thornton International (Ngo, 2019). However, there are arguments about the role of female in management activity, especially risk management. Some opinions point that the female has many valuable personality traits to face up the risk such as calmness, adaptability, patience, flexibility, etc, which play a key role in decreasing risk in work. Contrary to this view, some argued that many barriers affect women's equal participation and access to management opportunities. For example, for the same job, women are paid less than men; women bear the burden of work and look after families, which is much larger than men or lack opportunity to expand social relationships, etc. Therefore, it is likely to impact on the enterprise's management effectiveness led by female. Based on these opposite views, the authors recognized that it is necessary 
to examine objectively the impact of CEO's gender on the bank risk.

The literature in Vietnam has been showing that there is very little research on factors affecting banks' overall risk. Based on this gap, this paper will construct a model to examine determinants of the risk in Vietnamese commercial banks in the period from 2008 to 2018. Especially, our aim in this research is to provide new evidence on the relationship between the gender of CEOs and bank risk. We use a dataset of the Vietnamese commercial banks from 2008 to 2018. The data consists of 216 observations on 32 banks, which account for approximately $75 \%$ of the number of banks in the Vietnamese banking system.

In this research, the authors utilized four dependent variables, namely, ZscoreROA, ZscoreROE, NPL and LLP, where ZscoreROA and ZscoreROE are used to measure the bank risk, which is prominently used in previous studies. The ratio of non-performing loans to total loans (NPL) and the ratio of loan loss provisions to total loans (LLP) is represented for the bank's credit risk. Nine independent variables are grouped into internal and external ones, including Equity/Assetit - the equity to the asset, DEP - the deposits, ROA - the bank performance, STA - the public or private status, SIZE - the size for the bank, CEO - the gender of CEO, GDP - the gross domestic product of Vietnam, INF - the overall inflation rate in Vietnam and LIR - the long-term lending interest rate. The test result showed that equity/asset, bank performance and economic growth have an inverse relationship with bank risk, while the size of the bank has a positive relationship with the bank risk. Moreover, the financial institution led by female faces with a higher overall risk level and credit risk than a bank led by a male.

The remainder of this paper consists of four sections. The second section reviews research related to the impact of board characteristic on bank risk. The third section proposes the methodology to build models to address alternative hypotheses. The fourth session presents the research results and discussions. The final session proposes some recommendations to improve the stability of Vietnamese commercial banks, in particular, and the Vietnamese financial system, in general.

\section{Literature Review}

Many papers have studied the impact of the bank's diverse board characteristics on bank risk. Board characteristics are exploited in many different aspects. Using a dataset of 11 Tunisian commercial banks during 10 years, starting from 1997, Rachdi and Ameur (2011) concluded that the board characteristics and structure play a fundamental role in bank performance and bank risk. Specifically, the smaller the board of the commercial bank, the more effective the bank's performance and the higher the risk the bank encounters. The independent director has a negative influence on bank performance, but has no impact on bank risk. The lower the percentage of the banks CEO's shareholdings, the lower the performance and the higher the risk the Tunisian commercial banks are exposed to.

Studying 52 largest commercial banks in China from 2003 to 2010, Liang, Xu, and Jiraporn (2013) showed that the board characteristics play a significant role in management activity. The authors pointed out that the number of board meetings and the percentage of independent directors positively impact, while board size has a significantly negative effect on bank performance. Moreover, the closer the board's political relationship, the lower the bank performance is. Other variables, namely, Duality (a dummy variable equal 1 if CEO is also chairman of the board and 0 otherwise), Busy Director (the percentage of directors who serve on three or more other boards), Foreign Director (percentage of directors who are foreigners), Old Director (Percentage of directors who are older than 70) and Female Director (percentage of directors who are female) do not influence bank performance.

Karkowska and Acedański (2019) studied the influence of a bank's board structure (size, independence, and members' affiliations) and quality (experience, background, and skills) on bank risk. Using a panel regression data of 239 commercial banks with 2,429 observations across 40 countries, the authors demonstrated that the board's size correlated negatively to bank risk, while an independent committee makes a significant change in decreasing the risk of the bank. Moreover, the quality of board members such as background and skills plays an important role in reducing the risk of the commercial bank.

Interestingly, some papers studied the impact of the board's gender on risk. Using the U.S. sample data, Jianakoplos and Bernasek (1998) examined the difference of risk decision-making of male and female. The test result showed that single women are usually more risk-averse than single men. When wealth increases, it increased risk tolerance. However, the level of risk for men increases faster than for women. When the number of children in a single women's household raises, it tends to decrease the percentage of risky assets with other conditions being constant, which contrasts with the case of the single man or couples.

Using a generalized least squares regression to study a sample of companies in the financial industry from 2003 to 2011, Yu et al. (2017) studied the relationship between the gender of leader and bank risk. The paper showed that the leadership's gender of each position impacts differently on the risk of the bank. The women taking on executives and directors are positively related to bank risk, while the women leading audit committee and corporate governance committee are negatively associated with the risk. However, 
in the financial crisis, women in all positions play an important role in decreasing bank risk.

Faccio et al. (2016) studied a dataset of companies in 18 countries with a variety of econometric techniques. The result of the research showed that the company operated by female CEOs has lower leverage, less volatile earnings, and higher survival opportunity than the company led by male CEOs. Moreover, transitions from male to female CEOs (or vice-versa) impact positively (negatively) bank risk. The survey result of Adam and Funk (2010) is the same with the research of Faccio et al. (2016). The authors assumed that the female on the board is less risk-averse than the male in the same position.

When examining the impact of CEO gender on the bank risk of 347 Polish cooperative banks, Skata and Weill (2018) demonstrated that the gender of the board is a fundamental factor in making a risky financial decision. In other words, the female-led bank usually faces up with less risk than that led by a male. However, credit risk in the bank headed by the female is not different from that headed by a male.

However, there are many arguments about the impact of CEO's gender on bank risk in Vietnam because of the characteristics of Asian women. The Vietnamese women, in particular, and the Asian women, in general, are at the intersection between modern and traditional trends. On the one hand, they are strong, assertive and ready to pursue their dreams. The latest research on "Women in business" in 2019 showed that Vietnam has the second-highest rate of female leaders in Asia at approximately $36 \%$ (behind the Philippines, with $37.46 \%$ ). To be a leader in a corporation, the Vietnamese women have many personality traits that suit facing risks such as caution, patience, etc. However, they also face some difficulties such as the responsibility for taking care of families outside of work, the lack of opportunities to build relationships and social prejudices about empowering women to be leader, which play a key role in deciding the effectiveness of the management work and the risk response. Therefore, with a quantitative method, the authors would like to examine the effect of the leader's gender on the bank risk. It is one of the unique points of this study.

\section{Research Methodology}

\subsection{Hypothesis Development}

Using survey data, Adam and Frunk (2010) showed that the male CEO is more risk-averse than his female counterpart Adam and Funk (2010). Especially, Skala and Weill (2018) studied the impact of CEO's gender for bank risk with a dataset of 365 Polish banks. They explored an interesting relationship between CEO's gender and bank risk. They found that banks led by female CEOs are less risky due to higher capital adequacy and equity to asset ratios
(Skata and Weill 2018). Consistent with Adam and Frunk (2010), Faccio and et al (2016), Skala and Weill (2018), we hypothesize that:

H1: The female-led banks exert a positive impact on the risk of the commercial bank in Vietnam.

Contrary to the study, Bellucci, Borisov, and Zazzaro (2010) concluded that female CEOs are more risk-averse and less self-confident, while male CEOs usually have more venture projects. In China, Liu et al. (2014) showed a different result that diversifying the CEO's gender plays an important role in improving bank performance (Liu, Wei và Xie 2014). Consistent with Bellucci et al. (2011), Liu et al. (2014), we hypothesize that:

H2: The female-led banks exert a negative impact on the risk of the commercial bank in Vietnam.

\subsection{Empirical Model}

To examine the link between CEO's gender and bank risk, we estimate the equation as follows:

$$
\begin{aligned}
\text { RISK }_{\mathrm{it}}= & \beta_{0}+\beta_{1} \text { Equity } \text { Asset }_{\mathrm{it}}+\beta_{2} \mathrm{DEP}_{\mathrm{it}}+\beta_{3} \mathrm{ROA}_{\mathrm{it}} \\
& +\beta_{4} \mathrm{STA}_{\mathrm{it}}+\beta_{5} \mathrm{SIZE}_{\mathrm{it}}+\beta_{6} \mathrm{CEO}+\beta_{7} \mathrm{GDP}_{\mathrm{it}} \\
& +\beta_{8} \mathrm{INF}_{\mathrm{it}}+\beta_{9} \mathrm{LIR}_{\mathrm{it}}+\varepsilon_{\mathrm{it}}
\end{aligned}
$$

Where:

RISK $_{\text {it }}$ is independent variable indicating overall risk for bank $\mathrm{i}$ on year $\mathrm{t}$

Equity/Asset ${ }_{i t}$ is the equity to asset for bank $i$ at the time $t$ $\mathrm{DEP}_{i t}$ is the deposits for bank $i$ at the time $t$

$\mathrm{ROA}_{i \mathrm{i}}$ is the bank performance for bank $\mathrm{i}$ at the time $\mathrm{t}$

$\mathrm{STA}_{\mathrm{it}}$ is the public or private status for bank $i$ at the time $t$

SIZE $_{i t}$ is the size for bank $i$ at the time $t$

$\mathrm{CEO}_{\text {it }}$ is the gender of $\mathrm{CEO}$ for bank $i$ at the time $t$ year $\mathrm{t}$

$\mathrm{GDP}_{i t}$ is the gross domestic product of Vietnam on the

$\mathrm{INF}_{\text {it }}$ is the overall inflation rate in Vietnam on the year $t$

$\mathrm{LIR}_{\mathrm{it}}$ is the long-term lending interest rate on the year $t$

$\varepsilon_{\mathrm{it}}$ is a random error term

\subsubsection{The Dependent Variable}

Consistent with the research by Drakos et al. (2016), Khan et al. (2017), Skala and Weil (2017), the paper uses four indexes, namely, two Zscore indexes calculated by ROA and ROE, which has been the standard in the recent literature for measuring the overall risk of banks; the ratio of non-performing loans to total loans (NPL), and the ratio of 
loan loss provisions to total loans (LLP). NPL and LLP ratio are used often when measuring the credit risk.

The indexes are computed as follows:

$$
\begin{aligned}
\mathrm{Z}-\operatorname{score}(\mathrm{ROA}) & =\frac{\text { Return on Asset }+\left(\frac{\text { Equity }}{\text { Asset }}\right)}{\text { Standard Deviation of Return on asset }} \\
& =\frac{R O A+C A R}{\partial(R O A)}
\end{aligned}
$$

$$
\begin{aligned}
\mathrm{Z} \text {-score }(\mathrm{ROE}) & =\frac{\text { Return on Equity }+\left(\frac{\text { Equity }}{\text { Asset }}\right)}{\text { Standard Deviation of Return on equity }} \\
& =\frac{R O E+C A R}{\partial(R O E)}
\end{aligned}
$$

Where:

ROA is equal to earnings before taxes and loan loss provision divided by total assets

ROE is equal to earnings before taxes and loan loss provision divided by total equity

CAR is equal to equity divided by total assets

$\partial$ (ROA) is the standard deviation of ROA

$\partial$ (ROE) is the standard deviation of ROE

$$
\text { NPL }=\frac{\text { Total non }- \text { performing loans }}{\text { Total loan }}
$$

Bad debt is the total of debts classified from Group 3 to Group 5 according to the Decision 493/2005 / QD-NHNN dated April 22, 2005, of the State Bank of Vietnam.

$$
\text { LLP }=\frac{\text { Loan loss provisions }}{\text { Total loan }}
$$

Loan loss provisions are the total loss provision of five debt groups according to the Decision 493/2005 / QDNHNN dated April 22, 2005, of the State Bank of Vietnam. The lower Z-score implies higher bank risk. By contrast, the higher NPL and LLP, the less stable the bank. In other words, an increase in the NPL and LLP implies a higher credit risk.

\subsubsection{Independent Variables}

Based on the literature, the research paper has used nine variables, which are likely to impact on bank risk, of which six are interbank factors and three remaining variables are macroeconomic indicators. In addition to the variables used in previous studies, the authors have added a new variable, namely, female CEO to test the effect of the leader's gender on bank risk. All variables are computed as follows and summarized in Appendix A2.

\section{(i) Bank-specific factors}

The equity-to-asset ratio (Equity/Asset): This indicator reflects the ability of the enterprise's financial self-assurance and the level of financial independence. It is calculated by the ratio of total equity to total assets, which shows how much of the total asset is financed by the company's equity. The larger the value of the indicator, the greater the level of financial independence of enterprises (Qayyum \& Noreen, 2019). In other words, this higher index implies the higher ability to cope with risk and vice versa. The authors expect that banks with this higher variable correlate take the less overall bank risk.

Deposits (DEP): The research by Khan and et al (2017) proved that the banks having higher levels of deposits take less risk than the banks with lower levels of deposits. Because the banks with higher deposits are less likely to face a funding shortfall immediately, which decreases the risk of the bank. We expect this variable has a negative relationship with the bank risk.

Ownership structure (STA): The bank's ownership structure plays a fundamental role in preventing the commercial bank's risk. First, the state-owned banks listed are likely to access information rapidly, which causes the public bank's faster reaction to regulatory policy changes are likely to be faster for public banks, compared to private banks. Moreover, the public bank is subject to stronger market discipline and more stringent regulatory requirements. Therefore, the publicly-traded banks engage in less risky activities than their private counterparts (Samet et al., 2018). According to these arguments and application in Vietnam, we believe that exposure to risk in public banks is less than that in private banks.

Size of bank (SIZE): The previous studies have different views about the relationship between bank size and bank risk. In line with the too-big-to-fail hypothesis, many studies (Aspachs, Nier, \& Tiesset, 2005; Valla, SaesEscorbiac, \& Tiesset, 2006; Vodova, 2012) suggested that the greater the bank size, the lesser the bank risk since large-scale banks may have many advantages. Specifically, it is easier in raising capital from customers, lending on the interbank market or receiving support from the central bank as lender of last resort. However, Bunda and Desquilbet (2008) showed contradictory outcomes. The large-scale commercial banks typically enjoy implicit advantages with low cost for mobilizing capital. They often invest boldly in many venture projects. Hence, the risk of large-scale banks is also higher compared to smaller-scale banks. In this model, the authors expect a positive relationship between the size of the bank and the bank's stability. 
Bank performance (ROA): ROA represents bank performance. It the popular ratios measured by net income on total assets. ROA represents the level of efficiency when using the total asset. In other words, it reflects how much interest the company earns on 1 dong of the asset. The higher these figures, the better the ability to use assets (Tangngisalu et al., 2020). The authors assume that the bank with higher bank performance has an unfavorable relationship with risk (Banna, Ahmad, \& Koh, 2017).

CEO's gender (CEO): The larger gender difference is, the higher risk aversion of women (Powell and Ansic 1997). Other gender differences, such as in management styles, personality traits, etc, of CEOs also affect making decisions, which can have a detrimental or positive impact on bank risk. Based on the studies of Beccalli and Frantz (2009) and Skata and Weill (2018), we suppose that banks led by female CEOs are likely to be less risky, compared to banks led by a male.

\section{(ii) Macroeconomic factors}

Economic growth (GDP): Haas and Lelyveld (2008) concluded that GDP growth exerts a negative influence on subsidiaries' credit growth in the host country, seemingly indicating a portfolio adjustment toward higher return opportunities. According to one of the most basic tenets of investing, that high risk, high return, it is likely to increase bank risk. Some have argued that GDP growth should have a significant effect on the quality of credit (Tran \& Nguyen, 2020). Therefore, this would imply a lower risk density. In this paper, when considering the current situation in Vietnam, the authors expect a negative correlation between economic growth and the risk of banks.

Inflation (INF): Perry (1992) suggested that the effects of inflation on the bank's expectations about inflation in the near future. If inflation is expected to rise, banks will adjust interest rates to increase interest income faster than the speed of interest expense. However, the banks face uncertainty in predicting inflation. It not only increases costs, reduces the bank's net profit but also creates difficulties in mobilizing funds. Based on the studies (Bunda \& Desquilbet, 2008; Vodova, 2012; Fola, 2015), the writers expect that this relationship is positively correlated.

Long-term lending interest rate (LIR): The higher the long-term lending interest rate, the more profit the banks earns. As an evitable consequence, they will reduce the liquidity reserve for supporting long-term loans, which increases the risk for banks. These previous studies (Valla, Saes-Escorbiac, \& Tiesset, 2006; Bunda \& Desquilbet, 2008; Vodova, 2012) suggested that the lending rate is inversely correlated with the liquidity of banks. In this paper, we anticipate that an increase of long-term lending interest rate causes exposure to risk for banks.

\subsection{Data}

Our analysis is based on yearly bank-level data from annual financial statement of the commercial banks in Vietnam and data provided by the FiinGroup company, which is the leading firm in financial and business information in Vietnam, over a 10-year period, starting from 2008. All financial statements utilized to collect data in this research were published by the commercial banks, which ensure the accuracy of the database of this paper. We exclude banks having unreliable and missing information.

After collecting data, we choose 216 observations on 32 banks, which is a suitable number of samples needed for regression models. Some banks were excluded because of the missing data. The dataset in the research accounts for approximately $75 \%$ of the number of banks in the Vietnam banking system. The original information is calculated by formulas shown in Appendix.

\section{Results and Discussions}

\subsection{Descriptive Statistics}

Descriptive statistics of our measures of bank risk and determinants of the bank show that the average ZscoreROA of the Vietnamese commercial bank is 43.36. The ZscoreROA values range from 9.34 to 394.66 , with a high standard deviation of 48.97, which implies a strong variability in bank risk. The ZscoreROE value ranges from 1.67 to 28.92, with the lower standard deviation of 3.84. The values of two remaining dependent variables, namely, LLP and NPL have a small deviation of 0.01 and 0.02 , respectively. Especially, the average value of CEO is 0.10 , ranging from zero to one with a standard deviation of 0.30 , means that the number of male CEOs is much larger than the number of female $\mathrm{CEO}$ in the commercial banks in Vietnam. Table 1 provides summary statistics for female and male CEOs.

Overall, the data on the male CEO in the Vietnamese commercial banks accounts for approximately $89 \%$. In four indexes to measuring bank risk, the mean value of LLP of the bank with a female CEO is lower than that of the bank with a male CEO, 0.013990 compared to 0.014090 . By contrast, with three remaining risk measurements, namely, ZscoreROA, ZscoreROE and NPL, the bank having a female CEO has higher indexes than the bank led by a male CEO. The average value of the independent variables of the two groups has no significant difference.

The correlation matrix is shown in Table 2. It shows that some variables are highly correlated with other variables. Some pairs of specific variables have a high correlation coefficient such as (LIR, INF) and (LIR, GDP), 0.932 and -0.715 , respectively. Therefore, multicollinearity may be a problem with the regression model. We run the regression model and test its diagnostics in the next tables. 
Table 1: Descriptive statistics for female and male CEOs

\begin{tabular}{|l|c|c|c|c|c|c|c|c|c|c|}
\hline \multirow{2}{*}{ Variable } & \multicolumn{4}{|c|}{ Female CEO } & \multicolumn{5}{c|}{ Male CEO } \\
\cline { 2 - 12 } & Obs. & Mean & Max & Min & S.D. & Obs. & Mean & Max & Min & S.D. \\
\hline ZscoreROA & 23 & 88.35 & 450.66 & 9.24 & 136.53 & 193 & 78.40 & $1,518.67$ & 12.78 & 215.03 \\
\hline ZscoreROE & 23 & 7.75 & 27.98 & 2.67 & 7.77 & 193 & 7.36 & 67.32 & 1.67 & 9.54 \\
\hline LLP & 23 & .01 & .03 & .01 & .01 & 193 & .01 & .04 & .00 & .01 \\
\hline NPL & 23 & .03 & .12 & .01 & .03 & 193 & .02 & .09 & .00 & .01 \\
\hline Equity_Asset & 23 & .11 & .24 & .06 & .06 & 193 & .09 & .33 & .03 & .04 \\
\hline DEP & 23 & .68 & .86 & .36 & .12 & 193 & .63 & .89 & .28 & .13 \\
\hline ROA & 23 & .01 & .06 & .00 & .01 & 193 & .01 & .03 & .00 & .01 \\
\hline STA & 23 & - & - & - & - & 193 & .11 & 1.00 & - & .32 \\
\hline SIZE & 23 & 31.24 & 32.15 & 30.11 & .67 & 193 & 32.35 & 34.72 & 28.83 & 1.14 \\
\hline GDP & 23 & 3.36 & 5.01 & 1.81 & 1.04 & 193 & 3.47 & 5.54 & 1.25 & 1.09 \\
\hline INF & 23 & .08 & .19 & .01 & .05 & 193 & .07 & .23 & .01 & .05 \\
\hline LIR & 23 & 11.00 & 16.95 & 6.96 & 3.35 & 193 & 10.60 & 16.95 & 6.96 & 3.32 \\
\hline CEO & 23 & 1.00 & 1.00 & 1.00 & - & 193 & - & 1.00 & - & - \\
\hline
\end{tabular}

Table 2: Correlation between the main variables

\begin{tabular}{|l|c|c|c|c|c|c|c|c|c|c|c|c|}
\hline & $\begin{array}{c}\text { ZSCOR } \\
\text { EROA }\end{array}$ & $\begin{array}{c}\text { ZSCOR } \\
\text { EROE }\end{array}$ & LLP & NPL & $\begin{array}{c}\text { EQUITY } \\
\text { _ASSET }\end{array}$ & DEP & ROA & STA & SIZE & GDP & INF & LIR \\
\hline ZSCOREROA & 1.000 & & & & & & & & & & & \\
\hline ZSCOREROE & .735 & 1.000 & & & & & & & & & & \\
\hline LLP & .322 & .202 & .000 & & & & & & & & & \\
\hline NPL & .194 & .085 & .519 & .000 & & & & & & & & \\
\hline $\begin{array}{l}\text { EQUITY } \\
\text { ASSET }\end{array}$ & -.068 & .187 & -.162 & .086 & 1.000 & & & & & & & \\
\hline DEP & -.200 & -.354 & .089 & .080 & -.245 & 1.000 & & & & & & \\
\hline ROA & -.276 & .069 & -.159 & -.215 & .376 & -.296 & 1.000 & & & & & \\
\hline STA & .261 & .299 & .441 & .141 & -.220 & .084 & -.094 & 1.000 & & & & \\
\hline SIZE & -.009 & -.191 & .281 & -.063 & -.674 & .347 & -.130 & .451 & .000 & & & \\
\hline GDP & .039 & -.098 & .014 & -.010 & -.247 & .439 & -.307 & -.001 & .421 & 1.000 & & \\
\hline INF & -.025 & .107 & .090 & .052 & .177 & -.469 & .317 & .032 & -.203 & -.627 & 1.000 & \\
\hline LIR & -.010 & .104 & .093 & .092 & .208 & -.523 & .273 & .013 & -.278 & -.716 & .932 & 1.000 \\
\hline CEO & -.048 & -.089 & -.012 & .079 & .106 & .060 & -.027 & -.113 & -.246 & -.038 & .059 & .058 \\
\hline
\end{tabular}

\subsection{The Impact of CEO Gender on Bank Risk}

\section{CEO's gender and the overall bank risk:}

To examine the impact of CEO's gender on the overall bank risk, the study runs the regression model with nine independent variables and two dependent variables (ZscoreROA and ZscoreROE), which correspond to two models. With each model, the author performed regression techniques Pool OLS, Fixed-effect and Random effect in turn. Based on the F-test and Hausman Test, the most appropriate estimation results of each model are presented in Table 3.

The result of F-Test and Hausman test of four models pointed out that Prob (F-statistic) $=0.000000$, which means that the residual and the independent variables do not correlate. Therefore, we choose the fixed effect model is the best regression model to explain for the impact of CEO's gender on the bank risk. 
Table 3: The result of the regression model testing the impact CEO gender on the overall bank risk

\begin{tabular}{|c|c|c|c|c|c|c|}
\hline & \multicolumn{3}{|c|}{ Zscore(ROA) } & \multicolumn{3}{|c|}{ Zscore(ROE) } \\
\hline & $\begin{array}{l}\text { Pool OLS } \\
\text { (Model I) }\end{array}$ & $\begin{array}{l}\text { Fixed-effect } \\
\text { (Model II) }\end{array}$ & $\begin{array}{l}\text { Random-effect } \\
\text { (Model III) }\end{array}$ & $\begin{array}{l}\text { Pool OLS } \\
\text { (Model IV) }\end{array}$ & $\begin{array}{l}\text { Fixed-effect } \\
\text { (Model V) }\end{array}$ & $\begin{array}{l}\text { Random-effect } \\
\text { (Model VI) }\end{array}$ \\
\hline Constant & $\begin{array}{l}395.86^{* *} \\
(151.44)\end{array}$ & $\begin{array}{c}395.56^{* * *} \\
(117.57)\end{array}$ & $\begin{array}{c}344.99^{* * *} \\
(118.29)\end{array}$ & $\begin{array}{c}59.63^{* * *} \\
(11.07)\end{array}$ & $\begin{array}{c}40.27^{* * *} \\
(12.13)\end{array}$ & $\begin{array}{c}37.09^{* * *} \\
(11.49)\end{array}$ \\
\hline Equity/Asset & $\begin{array}{c}-45.69 \\
(103.41)\end{array}$ & $\begin{array}{c}140.24^{* * *} \\
(3653872)\end{array}$ & $\begin{array}{c}142.46^{* * *} \\
(39.18)\end{array}$ & $\begin{array}{l}-1.80 \\
(7.56)\end{array}$ & $\begin{array}{l}6.59^{\star} \\
(3.77)\end{array}$ & $\begin{array}{l}6.75^{\star} \\
(4.06)\end{array}$ \\
\hline DEP & $\begin{array}{c}-133.26^{* * *} \\
(28.46)\end{array}$ & $\begin{array}{l}22.98^{* *} \\
(10.75)\end{array}$ & $\begin{array}{c}18.31 \\
(11.54)\end{array}$ & $\begin{array}{c}-10.59^{* * *} \\
(2.08)\end{array}$ & $\begin{array}{c}0.84 \\
(1.11)\end{array}$ & $\begin{array}{l}-0.06 \\
(1.20)\end{array}$ \\
\hline ROA & $\begin{array}{c}-2133.07^{* * *} \\
(151.44)\end{array}$ & $\begin{array}{c}276.41 \\
(175.01)\end{array}$ & $\begin{array}{c}176.52 \\
(118.29)\end{array}$ & $\begin{array}{c}12.92 \\
(37.69)\end{array}$ & $\begin{array}{c}139.05^{\star * *} \\
(18.05)\end{array}$ & $\begin{array}{c}126.31^{* * *} \\
(19.53)\end{array}$ \\
\hline STA & $\begin{array}{c}53.42^{* * *} \\
(11.59)\end{array}$ & $\begin{array}{c}6.75 \\
(6.53)\end{array}$ & $\begin{array}{l}12.92^{*} \\
(6.89)\end{array}$ & $\begin{array}{l}6.49^{* * *} \\
(0.85)\end{array}$ & $\begin{array}{l}-0.34 \\
(0.67)\end{array}$ & $\begin{array}{c}0.74 \\
(0.70)\end{array}$ \\
\hline SIZE & $\begin{array}{c}-7.65^{* * *} \\
(4.76)\end{array}$ & $\begin{array}{c}-12.49^{* * *} \\
(3.79)\end{array}$ & $\begin{array}{c}(-10.46)^{\star * *} \\
(3.82)\end{array}$ & $\begin{array}{c}-1.48^{* * *} \\
(0.35)\end{array}$ & $\begin{array}{c}-1.18^{* * *} \\
(0.39)\end{array}$ & $\begin{array}{c}-1.03^{* * *} \\
(0.37)\end{array}$ \\
\hline GDP & $\begin{array}{l}4.67^{* *} \\
(4.42)\end{array}$ & $\begin{array}{l}5.18^{* *} \\
(2.05)\end{array}$ & $\begin{array}{l}4.19^{* *} \\
(2.10)\end{array}$ & $\begin{array}{l}6.29^{*} \\
(3.23)\end{array}$ & $\begin{array}{l}4.33^{* *} \\
(2.11)\end{array}$ & $\begin{array}{l}3.56^{*} \\
(2.08)\end{array}$ \\
\hline INF & $\begin{array}{c}58.96 \\
(157.80)\end{array}$ & $\begin{array}{c}0.43 \\
(42.72)\end{array}$ & $\begin{array}{c}3.64 \\
(46.24)\end{array}$ & $\begin{array}{c}12.82 \\
(11.54)\end{array}$ & $\begin{array}{c}5.61 \\
(4.41)\end{array}$ & $\begin{array}{c}6.00 \\
(4.83)\end{array}$ \\
\hline LIR & $\begin{array}{l}-2.07 \\
(2.87)\end{array}$ & $\begin{array}{c}0.23 \\
(0.78)\end{array}$ & $\begin{array}{c}0.10 \\
(0.86)\end{array}$ & $\begin{array}{l}-0.29 \\
(0.21)\end{array}$ & $\begin{array}{l}-0.06 \\
(0.08)\end{array}$ & $\begin{array}{l}-0.08 \\
(0.09)\end{array}$ \\
\hline Female CEO & $\begin{array}{c}-4.73 \\
(10.31)\end{array}$ & $\begin{array}{c}-10.623^{* * *} \\
(3.64)\end{array}$ & $\begin{array}{c}-10.92^{* * *} \\
(3.93)\end{array}$ & $\begin{array}{l}-1.32^{*} \\
(0.75)\end{array}$ & $\begin{array}{l}-0.68^{*} \\
(0.38)\end{array}$ & $\begin{array}{l}-0.76^{*} \\
(0.41)\end{array}$ \\
\hline Prob (F-Statistic) & 0.000000 & 0.000000 & 0.000000 & 0.000000 & 0.000000 & 0.000000 \\
\hline R-squared & 0.25 & 0.32 & 0.32 & 0.35 & 0.45 & 0.44 \\
\hline $\begin{array}{l}\text { Durbin-Watson } \\
\text { statistic }\end{array}$ & 0.30 & 1.6 & 1.11 & 0.42 & 1.75 & 1.22 \\
\hline$F$ test, Prob $>F$ & & $\begin{array}{l}0.0000 \\
(97.59)\end{array}$ & & & $\begin{array}{l}0.0000 \\
(46.12)\end{array}$ & \\
\hline $\begin{array}{l}\text { Hausman test } \\
\text { Prob> chi2 }\end{array}$ & & & $\begin{array}{l}0.0000 \\
(57.94)\end{array}$ & & & $\begin{array}{l}0.0000 \\
(59.50)\end{array}$ \\
\hline $\begin{array}{l}\text { Akaike Information } \\
\text { standard (AIC) }\end{array}$ & & 7.83 & & & 3.28 & \\
\hline $\begin{array}{l}\text { Schwarz } \\
\text { Information } \\
\text { standard (SC) }\end{array}$ & & 8.45 & & & 3.91 & \\
\hline No.obs & 216 & 216 & 216 & 216 & 216 & 216 \\
\hline
\end{tabular}

Note: Statistically significant at ${ }^{*} 10 \%,{ }^{* *} 5 \%,{ }^{* * *} 1 \%$

The two fixed-effect models namely Model II, Model $\mathrm{V}$ have Prob (F-statistic) are lower than 0.01, which proves that the models are statistically significant at $1 \%$. Moreover, approximately $32.3 \%$, $44.93 \%$ of changes in Zscore(ROA), Zscore(ROE) can be explained by independent variables respectively.

Moreover, Model II which Zscore (ROA) are represented for risk of the bank system, the CEO's gender impacts on the stability of the bank with statistically significant at $1 \%$ respectively while with Zscore(ROE) as the dependent variable, the CEO's gender affect bank risk with statistically significant at $5 \%$. Female CEO is significantly negative with Zscore(ROA) and Zscore(ROE) while this variable has an inverse correlation with the risk of the bank. Thus, it supports the view that banks led by female directors are associated with higher insolvency risk. 
Testing the most appreciated model by Akaike info criterion (AIC) and Schwarz criterion (SC), the result is shown in Table 4. The smaller the AIC and SC values, the more suitable the model (Mohammed et al, 2015). Based on the table above, we see that Model V has smaller AIC and $\mathrm{SC}$ values. This proves that Model $\mathrm{V}$ is stronger than the Model II.

\section{Testing for the model's diagnostics:}

Test for omitting variables: We can see that the variables, namely, DEP, STA, INF, LIR, are not statistically significant. We use the Wald Test to examine whether to eliminate or not, we have P-value of F-statistic $=0,73>0.05$, therefore, we can eliminate these variables, but not affect the result of the model.

Test for multicollinearity: We use Variance Inflation Factors (VIF) to test for multicollinearity. The results show that the VIFs of the dependent variables are lower than 10 and Mean VIF is 1.7, which implies that multicollinearity is not an issue of this model.

Test for autocorrelation: We use Durbin-Watson to test autocorrelation. Durbin Watson statistic of the model is 1.75 , which is within a range from 1 to 3 . Therefore, autocorrelation is not a problem with this model.

Test for heteroskedasticity: The White test is used to test the heteroskedasticity error in Fixed-effect model. The result shows that Prob $>$ Chi $2=0.0000$, which is lower than 0.05 . Therefore, the model has heteroskedasticity problem. We overcome this disability by weighting method according to the opinion of White (1980) by Robust Standard Error. We have the new model after addressing all problem as follows: Equity_Asset, ROA, SIZE, GDP, CEO with coefficient correspondent are 8.00, 138.43, (1.15), 4.28, (0.62) at significant statistic at $* * 5 \%, * * * 1 \%$. The results ensure reliability with R-square, which is 42.54 .

Determinants of the Vietnamese commercial bank's risk and the impact of $\mathrm{CEO}$ gender on the Vietnamese commercial bank's risk:

Approximately $43 \%$ of the change in the dependent variable is explained by the independent variable. The test result shows that equity/asset, ROA and GDP have a positive correlation with the independent variable ZscoreROE, which has an inverse relationship with bank risk. Therefore, these variables negatively correlated with bank risk. The test result is suitable for the authors' expectation (see Table 4).

Moreover, the variable SIZE has a negative correlation with ZscoreROE, which implies that it has a positive relationship with the bank risk. This test result is consistent with Bunda and Desquilbet (2008) and contrary to the authors' expectation as well as some previous research such as Aspachs et al. (2005), and Valla et al. (2006).

Especially, the female CEO variable has a negative correlation with the dependent variable (ZscoreROE). Moreover, the dependent variable has an inverse relationship with the risk-taking of the bank system. Consequently, the banks led by female directors are associated with higher insolvency risk. This result is contrary to the authors' hypothesis and the previous research by Bellucci et al. (2010) and Skata and Weill (2018), which points out that the banks led by female CEOs are less risky. However, considering the Vietnamese working environment, the authors realize that this result is reasonable. The Vietnamese businesses run by women are usually less financially efficient than the ledmale corporation because the operation of a woman often has few negotiation experience and skill as well as time for work.

Table 4: Determinants of the Vietnamese commercial bank's risk

\begin{tabular}{|c|c|c|c|c|c|}
\hline \multirow{2}{*}{ No. } & \multirow{2}{*}{ Acronym } & \multirow{2}{*}{ The name of variables } & \multirow{2}{*}{$\begin{array}{c}\text { Expectation } \\
\text { (with bank risk) }\end{array}$} & \multicolumn{2}{|c|}{ The test result } \\
\hline & & & & With ZscoreROE & With bank risk \\
\hline 1 & Equity/Asset & The equity to asset ratio & - & + & - \\
\hline 2 & DEP & Deposits & - & No affect & No affect \\
\hline 3 & ROA & The bank performance & - & + & - \\
\hline 4 & STA & Ownership structure & - & No affect & No affect \\
\hline 5 & SIZE & The size for bank & - & - & + \\
\hline 6 & CEO & Female CEO & $+/-$ & - & + \\
\hline 7 & INF & Inflation rate & + & No affect & No affect \\
\hline 8 & LIR & The long-term lending interate rate & - & No affect & No affect \\
\hline 9 & GDP & Gross domestic product & - & + & - \\
\hline
\end{tabular}


Table 5: The result of the regression model testing the impact CEO gender on the credit risk

\begin{tabular}{|c|c|c|c|c|c|c|}
\hline \multirow[b]{2}{*}{ Variables } & \multicolumn{3}{|c|}{ LLP } & \multicolumn{3}{|c|}{ NPL } \\
\hline & $\begin{array}{c}\text { Pool OLS } \\
\text { (Model VII) }\end{array}$ & $\begin{array}{l}\text { Fixed-effect } \\
\text { (Model VIII) }\end{array}$ & $\begin{array}{c}\text { Random-effect } \\
\text { (Model IX) }\end{array}$ & $\begin{array}{l}\text { Pool OLS } \\
\text { (Model X) }\end{array}$ & $\begin{array}{c}\text { Fixed-effect } \\
\text { (Model XI) }\end{array}$ & $\begin{array}{c}\text { Random - effect } \\
\text { (Model XII) }\end{array}$ \\
\hline Constant & $\begin{array}{l}-0.0283 \\
(0.0202)\end{array}$ & $\begin{array}{l}-0.0873^{*} \\
(0.0479)\end{array}$ & $\begin{array}{c}-0.0681^{* * *} \\
(0.0254)\end{array}$ & $\begin{array}{c}0.1234 \\
(0.0506)\end{array}$ & $\begin{array}{c}0.1120 \\
(0.1387)\end{array}$ & $\begin{array}{c}-0.0681^{* * *} \\
(0.0252)\end{array}$ \\
\hline Equity/Asset & $\begin{array}{c}0.0105 \\
(0.0138)\end{array}$ & $\begin{array}{l}0.0384^{\star *} \\
(0.0149)\end{array}$ & $\begin{array}{l}0.0271^{*} \\
(0.0142)\end{array}$ & $\begin{array}{l}0.0642^{*} \\
(0.0346)\end{array}$ & $\begin{array}{l}0.0828^{*} \\
(0.0431)\end{array}$ & $\begin{array}{c}0.0271^{*} \\
0.0142\end{array}$ \\
\hline DEP & $\begin{array}{c}0.0032 \\
(0.0037)\end{array}$ & $\begin{array}{l}0.0112^{* *} \\
(0.0044)\end{array}$ & $\begin{array}{c}0.0056 \\
(0.0040)\end{array}$ & $\begin{array}{l}0.0163^{*} \\
(0.0095)\end{array}$ & $\begin{array}{l}0.0299^{* *} \\
(0.0127)\end{array}$ & $\begin{array}{l}0.0056 \\
0.0040\end{array}$ \\
\hline ROA & $\begin{array}{l}-0.1405^{\star *} \\
(0.0687) \\
\end{array}$ & $\begin{array}{l}-0.0544 \\
(0.0714) \\
\end{array}$ & $\begin{array}{l}-0.1319^{*} \\
(0.0695) \\
\end{array}$ & $\begin{array}{c}-0.5588^{* * *} \\
(0.1724) \\
\end{array}$ & $\begin{array}{c}-0.2519 \\
(0.2064) \\
\end{array}$ & $\begin{array}{c}-0.1320^{*} \\
0.0696 \\
\end{array}$ \\
\hline STA & $\begin{array}{c}0.0077^{* * *} \\
(0.0015)\end{array}$ & $\begin{array}{c}-0.0060^{* *} \\
(0.0027)\end{array}$ & $\begin{array}{l}0.0048^{* *} \\
(0.0020)\end{array}$ & $\begin{array}{l}0.0088^{* *} \\
(0.0039)\end{array}$ & $\begin{array}{l}-0.0025 \\
(0.0077)\end{array}$ & $\begin{array}{c}0.0048^{* *} \\
0.0020\end{array}$ \\
\hline SIZE & $\begin{array}{c}0.0010 \\
(0.0006)\end{array}$ & $\begin{array}{l}0.0028^{*} \\
(0.0015)\end{array}$ & $\begin{array}{c}0.0023^{* * *} \\
(0.0008)\end{array}$ & $\begin{array}{l}-0.0007 \\
(0.0016)\end{array}$ & $\begin{array}{l}-0.0044 \\
(0.0045)\end{array}$ & $\begin{array}{c}0.0023^{* * *} \\
(0.0008)\end{array}$ \\
\hline GDP & $\begin{array}{l}2.9700 \\
5.9000\end{array}$ & $\begin{array}{l}-5.1200 \\
(8.3500)\end{array}$ & $\begin{array}{l}-3.6600 \\
(5.8500)\end{array}$ & $\begin{array}{c}1.5300 \\
(1.4800)\end{array}$ & $\begin{array}{c}3.4600 \\
(2.4100)\end{array}$ & $\begin{array}{l}-3.6600 \\
(5.5800)\end{array}$ \\
\hline INF & $\begin{array}{l}-0.0060 \\
(0.0210)\end{array}$ & $\begin{array}{c}0.0042 \\
(0.0174)\end{array}$ & $\begin{array}{c}0.0002 \\
(0.0188)\end{array}$ & $\begin{array}{l}-0.0479 \\
(0.0528)\end{array}$ & $\begin{array}{l}-0.0423 \\
(0.0504)\end{array}$ & $\begin{array}{c}0.0002 \\
(0.0188)\end{array}$ \\
\hline LIR & $\begin{array}{c}0.0005 \\
(0.0003)\end{array}$ & $\begin{array}{c}0.0004 \\
(0.0003)\end{array}$ & $\begin{array}{c}0.0004 \\
(0.0034)\end{array}$ & $\begin{array}{l}0.0019^{* *} \\
(0.0010)\end{array}$ & $\begin{array}{l}0.0019^{* *} \\
(0.0009)\end{array}$ & $\begin{array}{l}0.0004 \\
0.0003 \\
\end{array}$ \\
\hline Female CEO & $\begin{array}{c}0.0010 \\
(0.0013)\end{array}$ & $\begin{array}{c}0.0039^{* * *} \\
(0.0015)\end{array}$ & $\begin{array}{c}0.0023 \\
(0.0014)\end{array}$ & $\begin{array}{c}0.0021 \\
(0.0034)\end{array}$ & $\begin{array}{l}0.0118^{* * *} \\
(0.0043)\end{array}$ & $\begin{array}{c}0.0023 \\
(0.0014)\end{array}$ \\
\hline Prob (F-Statistic) & 0.0000 & 0.0000 & 0.0000 & 0.0002 & 0.0002 & 0.0002 \\
\hline R-squared & 0.2494 & 0.1534 & 0.5157 & 0.1421 & 0.1633 & 0.5157 (within) \\
\hline $\mathrm{F}$ test, Prob $>\mathrm{F}$ & & $\begin{array}{c}0.0000 \\
(5.2163)\end{array}$ & & & $\begin{array}{c}0.0002 \\
(2.4532) \\
\end{array}$ & \\
\hline $\begin{array}{l}\text { Hausman test } \\
\text { Prob }>\text { chi2 }\end{array}$ & & & $\begin{array}{c}0.0000 \\
(50.7302)\end{array}$ & & & $\begin{array}{c}0.0054 \\
(23.3868)\end{array}$ \\
\hline $\begin{array}{l}\text { Akaike } \\
\text { Information } \\
\text { standard (AIC) }\end{array}$ & & -7.7836 & & & -5.6598 & \\
\hline $\begin{array}{l}\text { Schwarz } \\
\text { Information } \\
\text { standard (SC) }\end{array}$ & & -7.1585 & & & -5.0348 & \\
\hline No.obs & 216 & 216 & 216 & 216 & 216 & 216 \\
\hline
\end{tabular}

Note: Statistically significant at ${ }^{*} 10 \%,{ }^{* *} 5 \%,{ }^{* * *}$

\section{CEO gender and the commercial bank's credit risk:}

When testing of CEO's gender on the credit risk by running the regression model with nine independent variables and two dependent variables (LLP and NPL), the authors run Pool OLS, Fixed-effect and Random effect. Based on the F-test and Hausman Test with Prob (F-statistic) $=0.000000$, the fixed-effect model is the best regression model to explain for the impact of CEO's gender on the bank credit risk.
Prob (F-statistic) of two fixed-effect models is lower than 0.01 , which proves that the models are statistically significant at $1 \%$. R-squared of Model VIII and Model XI are 0.1534 and 0.1633 , respectively. In other words, approximately $15.34 \%$ and $16.33 \%$ of changes in LLP and NPL can be explained by independent variables, respectively.

In both models, the CEO's gender influence on the credit risk is statistically significant at $1 \%$. Female CEO 
is significantly positive with NPL and LLP, while these variable has a positive correlation with the credit risk of the bank. Therefore, it is concluded that banks led by female directors are associated with higher credit risk. Using AIC and SC, we see that the Model VIII has smaller AIC and $\mathrm{SC}$ values, which proves that Model VIII is more suitable than Model XI. After examining and solving the problem of the model VIII, the research paper concluded that the bank whose leader is female has higher credit risk, compared to the bank whose leader is male (see Table 5).

\subsection{Conclusions}

In this study, we examined hypotheses relating to the risk-taking of the Vietnamese bank after the global crisis in 2008. To achieve this goal, we used a unique dataset of 216 observations from 31 Vietnamese banks, from 2008 to 2018. We used panel data to run OLS regression models, Random effect and Fixed effect by Eviews and STATA. The results in the paper are inconsistent with the findings of Haas and Lelyveld (2008), which indicate that economic growth has a positive correlation with the bank risk. In the case of Vietnamese commercial banks, strong economic growth plays a key role in boosting the enterprise's business and promoting revenue for the repay the bank, which is decreasing the bank risk. Conversely, a slow-developing economy impacts negatively on bank risk.

The current situation of the Vietnamese commercial banking is a typical example. COVID-19 epidemic has a very bad impact on Vietnam's economic growth since the beginning of the year. According to the survey by the Vietnam Chamber of Commerce and Industry (VCCI), nearly $85 \%$ of businesses said their consumption markets were narrowed; $60 \%$ of the enterprises are lacking capital and business cash flow is cut and 30\% of enterprises can maintain operation for no more than three months. More than at any time, the banking industry is at great risk due to enterprises unable to pay debts. This is exacerbated by the government's implementation of social isolation to prevent epidemic spreading. Therefore, the measures to restore the economy should be considered and implemented by the Government early to avoid risks to banks.

The higher the equity-to-asset ratio and the bank performance, the lower the bank risk. The high equity-toasset plays a fundamental role in increasing the bank's level of financial independence, which implies the higher ability to cope with risk. The high return-on-asset index means the high efficiency to use assets of the bank, which increase the bank's stability. Moreover, the variable SIZE has a positive relationship with the bank risk, which is contrary to the authors' expectation. Due to implicit advantages in mobilizing capital, the large-scale commercial banks often invest in many venture projects, which is likely to raise the risk for the big-size banks. It is necessary for the State Bank of Vietnam to enhance the inspection and supervision of banks, especially in the large-scale bank.

One of the highlights of this study is the finding of the relationship between the gender of the CEO and the bank risk-taking in Vietnam. It emphasized that the banks led by female usually faces higher risk than that led by a male. This result is opposite to many previous studies, however, it is reasonable when applied to the Vietnamese case. According to a survey of Navigos Group, which is one of the biggest groups providing personnel recruitment services, the female usually has to cope with invisible barriers. The female CEOs in Vietnam deal with difficulties in balancing work and family and lack of support and sympathy from their family. Moreover, some social prejudices still exist in Vietnam. Many people still believe that women are too soft to run their businesses, which breeds non-beneficial results in negotiating and engaging in large contracts (Nguyen 2018). Our conclusion is of particular importance to the banking system, which implies that demographic characteristics of bank managers should be considered carefully with the position of the banking industry under pressure.

\section{References}

Adam, R. B., \& Funk, P. (2010). Beyond the Glass Ceiling: Does Gender Matter? UPF Working Paper Series - Finance Working Paper No. 273/2010. European Corporate Governance Institute (ECGI). Available at SSRN: http://dx.doi.org/10.2139/ ssrn. 1475152

Aspachs, O., Nier, E., \& Tiesset, M. (2005), Liquidity, banking regulation and the macroeconomy: Evidence on bank liquidity holdings from a panel of UK-resident banks. Bis.org. Retrieved December 12, 2019, from: https://www.bis.org/bcbs/events/ rtf05AspachsNierTiesset.pdf

Banna, H., Ahmad, R., \& Koh, E. H. Y. (2017). Determinants of Commercial Banks' Efficiency in Bangladesh: Does Crisis Matter? Journal of Asian Finance, Economics and Business, 4(3), 19-26. http://dx.doi.org/10.13106/jafeb.2017.vol4.no3.19

Barucci, E., \& Milani, C. (2018). Do European banks manipulate risk weights? International Review of Financial Analysis, 59, 47-57. https://doi.org/10.1016/j.irfa.2018.07.002

Beccalli, E., \& Frantz, P. (2009). M\&A Operations and Performance in Banking. Journal of Financial Services Research, 36, 203-226. https://doi.org/10.1007/s10693-008-0051-6

Bellucci, A., Borisov, A., \& Zazzaro, A. (2010), Does gender matter in bank-firm relationship? Evidence from small business lending, Journal of Banking and Finance, 34(12), 2968-2984. https://doi.org/10.1016/j.jbankfin.2010.07.008

Bunda, I., \& Desquilbet, J.-B. (2008). The bank liquidity smile across exchange rate regimes. International Economic Journal, 22(3), 361-386. http://doi.org/10.1080/10168730802287952 
Drakos, A. A., Kouretas, G. P., \& Tsoumas, C. (2016). Ownership, interest rates and bank risk-taking in Central and Eastern European countries. International Review of Financial Analysis, 45, 308-319. https://doi.org/10.1016/j.irfa.2014.08.004

Mohammed, E. A., Naugler, C., \& Far, B. H. (2015). Emerging Business Intelligence Framework for a Clinical Laboratory through Big Data Analytics. Emerging Trends in Computational Biology, Bioinformatics, and Systems Biology, 2015, 577-602. http://doi.org/10.1016/b978-0-12-802508-6.00032-6

Faccio, M., Marchica, M.-T., \& Mura, R. (2016). CEO gender, corporate risk-taking, and the efficiency of capital allocation. Journal of Corporate Finance, 39, 193-209. https://doi. org/10.1016/j.jcorpfin.2016.02.008

Fola, B. (2015). Factors Affecting Liquidity of Selected Commercial Banks in Ethiopia. Master's thesis. The Department of Accounting and Finance, Addis Ababa University. Ethiopia.

De Haas, R., \& Lelyveld, I. (2010). Internal capital markets and lending by multinational bank subsidiaries. Journal of Financial Intermediation, 19(1), 1-25. https://doi.org/10.1016/j. jfi.2009.02.001

Ngo, V. K. T. (2019). Vietnam is ranked the second most women in senior management among Asian countries. Grantthornton. Retrieved December 28, 2019, from: https://www.grantthornton. com.vn/press/press-release-2019/women-in-business/

Jianakoplos, N. A., \& Bernasek, A. (1998). Are women more risk averse? Economic Inquiry, 36(4), 620-630. http://dx.doi. org/10.1111/j.1465-7295.1998.tb01740.x

Karkowska, R., \& Acedański, J. (2019). The effect of corporate board attributes on bank stability. Portuguese Economic Journal, 19, 99-137. http://dx.doi.org/10.1007/s10258-01900162-3

Khan, M. S., Scheule, H., \& Wu, E. (2017). Funding liquidity and bank risk taking. Journal of Banking and Finance, 82(C), 203-216. http://dx.doi.org/10.1016/j.jbankfin.2016.09.005

Liang, Q., Xu, P., \& Jiraporn, P. (2013). Board characteristics and Chinese bank performance. Journal of Banking \& Finance, 37(8), 2953-2968. http://doi.org/10.1016/j. jbankfin.2013.04.018

Liu, Y., Wei, Z., \& Xie, F. (2014). Do women directors improve firm performance in China? Journal of Corporate Finance, 28, 169-184. https://doi.org/10.1016/j.jcorpfin.2013.11.016

Nguyen, T. (2018). Female leaders face many invisible barriers. Tinnhanhchungkhoan. Retrieved January 15, 2020, from: https://tinnhanhchungkhoan.vn/doanh-nhan/lanh-dao-nu-doimat-voi-nhieu-rao-can-vo-hinh-232136.html [Vietnamese]

Perry, P. (1992). Do banks gain or lose from inflation. Journal of Retail Banking, 14(2), 25-30.
Powell, M., \& Ansic, D. (1997). Gender Differences in Risk Behaviour in Financial Decision-Making: An Experimental Analysis. Journal of Economic Psychology, 18, 605-628.

Qayyum, N. U., \& Noreen, U. (2019). Impact of Capital Structure on Profitability: A Comparative Study of Islamic and Conventional Banks of Pakistan. Journal of Asian Finance, Economics and Business, 6(4), 65-74. https://doi.org/10.13106/ jafeb.2019.vol6.no4.65

Rachdi, H., \& Ben Ameur, I. G. (2011). Board Characteristics, Performance and Risk Taking Behaviour in Tunisian Banks. International Journal of Business and Management, 6(6), 88-98. http://dx.doi.org/10.5539/ijbm.v6n6p88

Saif-Alyousfi, A. Y. H., Saha, A., \& Md-Rus, R. (2018). The impact of bank competition and concentration on bank risktaking behavior and stability: Evidence from GCC countries. The North American Journal of Economics and Finance, 51, 100867. http://dx.doi.org/10.1016/j.najef.2018.10.015

Samet, A., Boubakri, N., \& Boubaker, S. (2018). Does public-private status affect bank risk taking? Worldwide evidence. Journal of International Financial Markets, Institutions and Money, 53, 287-306. http://dx.doi.org/10.1016/j.intfin.2017.12.007

Shaban, M., \& James, G. A. (2018). The effects of ownership change on bank performance and risk exposure: Evidence from Indonesia. Journal of Banking \& Finance, 88, 483-497. http:// dx.doi.org/10.1016/j.jbankfin.2017.02.002

Skała, D., \& Weill, L. (2018). Does CEO gender matter for bank risk? Economic Systems, 42(1), 64-74. http://dx.doi. org/10.1016/j.ecosys.2017.08.005

Tangngisalu, J., Hasanuddin, R., Hala, Y., Nurtlina, N. \& Syahrul, S. (2020). Effect of CAR and NPL on ROA: Empirical study in Indonesia banks. Journal of Asian Finance, Economics and Business, 7(6), 9-18. http://dx.doi.org/10.13106/jafeb.2020. vol7.no6.009

Tran, S. H., \& Nguyen, T. L. (2020). Financial Development, Business Cycle and Bank Risk in Southeast Asian Countries. Journal of Asian Finance, Economics and Business, 7(3), 127-135. https://doi.org/10.13106/jafeb.2020.vol7.no3.127

Valla, N., Saes-Escorbiac, B. \& Tiesset, M. (2006). Bank liquidity and financial stability, Financial Stability Review, 9, 89-104.

Vodova. (2012), Liquidity of Czech and Slovak commercial banks. Econpapers. Retrieved January 20, 2020, from: https://econpapers.repec.org/article/mupactaun/ actaun_5f2012060070463.htm

Yu, B., Lenard, M. J., York, E. A., \& Wu, S. (2017). Female leadership in banking and bank risk. Academy of Accounting and Financial Studies Journal, 21(3), 1-19. 


\section{Appendix}

\begin{tabular}{|c|c|c|c|c|c|c|}
\hline No. & Acronym & $\begin{array}{l}\text { The } \\
\text { desc }\end{array}$ & $\begin{array}{l}\text { ariable } \\
\text { iption }\end{array}$ & \multirow{2}{*}{\multicolumn{2}{|c|}{ The reference papers }} & $\begin{array}{l}\text { Relation-ship } \\
\text { with bank risk }\end{array}$ \\
\hline A1 & \multicolumn{3}{|c|}{ The dependent variables } & & & \\
\hline 1 & Zscore(ROA) & \multicolumn{2}{|c|}{$Z_{i t}=\frac{R O A i t+C A R i t}{\sigma(R O A) i t}$} & \multicolumn{2}{|l|}{$\begin{array}{l}\text { Drakos et al. (2016) } \\
\text { Skala and Weill (2017) } \\
\text { Samet et al. (2018) }\end{array}$} & - \\
\hline 2 & Zscore(ROE) & \multicolumn{2}{|c|}{$Z_{i t}=\frac{R O E i t+C A R \text { it }}{\sigma(R O E) i t}$} & \multicolumn{2}{|c|}{ Saif-Alyousfi et al. (2018) } & - \\
\hline 3 & NPL & \multicolumn{2}{|c|}{$\begin{array}{l}\text { The ratio of non- } \\
\text { performing loans to total } \\
\text { loans }\end{array}$} & \multicolumn{2}{|l|}{ Skala and Weill (2017) } & + \\
\hline 4 & LLP & \multicolumn{2}{|c|}{$\begin{array}{l}\text { The ratio of loan loss } \\
\text { provisions to total loans }\end{array}$} & \multicolumn{2}{|l|}{ Skala and Weill (2017) } & + \\
\hline A2 & \multicolumn{5}{|c|}{ The independent variables } & \\
\hline 1 & $\begin{array}{l}\text { Equity / } \\
\text { Asset }\end{array}$ & $\begin{array}{l}\text { The equity to } \\
\text { asset ratio }\end{array}$ & \multicolumn{2}{|c|}{ Equity/ Total assets } & & - \\
\hline 2 & DEP & Deposits & \multicolumn{2}{|c|}{ Total deposits/ Total assets } & (Khan, Scheule and Wu 2017); & - \\
\hline 3 & ROA & $\begin{array}{l}\text { The bank } \\
\text { performance }\end{array}$ & \multicolumn{2}{|c|}{ Net income on total assets } & & - \\
\hline 4 & STA & $\begin{array}{l}\text { Ownership } \\
\text { structure }\end{array}$ & \multicolumn{2}{|c|}{$\begin{array}{l}\text { We have used a dummy variable } \\
\text { as a notation of public bank. It } \\
\text { equals } 1 \text { if it is ownership from the } \\
\text { state higher than } 65 \% \text { of shares. } \\
\text { Otherwise, it equals } 0 .\end{array}$} & $\begin{array}{l}\text { (Samet, Boubakri and } \\
\text { Boubaker 2018); (Shaban and } \\
\text { James 2017) }\end{array}$ & - \\
\hline 5 & SIZE & $\begin{array}{l}\text { The size for } \\
\text { bank }\end{array}$ & \multicolumn{2}{|c|}{ Logarit (Toal assets) } & $\begin{array}{l}\text { (Aspachs, Nier and Tiesset } \\
\text { 2005), (Valla, Saes-Escorbiac } \\
\text { and Tiesset3 2006), (Vodova } \\
\text { 2012), (Bunda and Desquilbet } \\
\text { 2008), }\end{array}$ & - \\
\hline 6 & CEO & Female CEO & \multicolumn{2}{|c|}{$\begin{array}{l}\text { We have used dummy variables } \\
\text { to stand for gender of CEOs: } \\
\text { number } 1 \text { stands for female and } 0 \\
\text { for male. }\end{array}$} & $\begin{array}{l}\text { (Powell and Ansic 1997), } \\
\text { (Bellucci, Borisov and Zazzaro } \\
\text { 2010), (Skata and Weill 2018) }\end{array}$ & $+/-$ \\
\hline 7 & INF & Inflation rate & \multicolumn{2}{|c|}{$\begin{array}{l}\text { Inflation rate is calculated on the } \\
\text { basis of consumer price index CPI } \\
\text { at the end of quarter this year and } \\
\text { same quarter last year in Vietnam } \\
(\%) .\end{array}$} & $\begin{array}{l}\text { (Bunda and Desquilbet 2008), } \\
\text { (Vodova 2012), (Fola 2015), } \\
\text { Perry (1992) }\end{array}$ & + \\
\hline 8 & LIR & $\begin{array}{l}\text { The long- } \\
\text { term lending } \\
\text { interate rate }\end{array}$ & \multicolumn{2}{|c|}{$\begin{array}{l}\text { It is interest rate of loans in term } \\
\text { of } 60 \text { months or more. }\end{array}$} & $\begin{array}{l}\text { (Valla, Saes-Escorbiac and } \\
\text { Tiesset3 2006), (Bunda and } \\
\text { Desquilbet 2008), (Vodova } \\
\text { 2012), (Drakos, Kouretas and } \\
\text { Tsoumas 2016) }\end{array}$ & - \\
\hline 9 & GDP & $\begin{array}{l}\text { Gross } \\
\text { domestic } \\
\text { product }\end{array}$ & \multicolumn{2}{|c|}{$\begin{array}{l}\text { The increase/decrease speed in } \\
\text { GDP is compared with itself in the } \\
\text { same period last year }(\%) \text {. }\end{array}$} & $\begin{array}{l}\text { (Khan, Scheule and Wu 2017), } \\
\text { (Haas and Lelyveld 2008), } \\
\text { (Barucci and Milani 2018) }\end{array}$ & - \\
\hline
\end{tabular}

